\title{
Solving the WTO Dispute Settlement System Crisis
} An Introduction

\author{
Giorgio Sacerdoti \\ University of Bocconi, Milan, Italy \\ giorgio.sacerdoti@unibocconi.it
}

The three articles of this Special Issue Section, ${ }^{1}$ which I have the pleasure and privilege of introducing, represent major contributions to the current academic and diplomatic debate on the US-instigated World Trade Organization (WTO) Appellate Body's (AB) demise, its consequences and remedies. All three articles were initially presented as papers in a panel session on the current crisis of the WTO Dispute Settlement System (DSS) at the Society of International Economic Law (SIEL) Biennial Conference on 'International Economic Law in Unsettling Times' held at the American University, Washington College of Law in Washington D.C. in July 2018, but have been considerably revised and updated for the purpose of publication. They have not lost their relevance; on the contrary, the crisis has been going on and has even aggravated since July 2018 due to the United States' refusal to give a 'green light' to the renewal of the $\mathrm{AB}$ members. This is leading to the 'extinction' of the $\mathrm{AB}$ due to its membership falling below to the minimum three members required to decide cases on 10 December 2019.

The various criticisms by the United States of $\mathrm{AB}$ practices are an unacceptable basis for such a radical reaction as paralyzing the whole DSS and are contrary to good faith. ${ }^{2}$ The United States has moreover refused until now to engage

* Giorgio Sacerdoti is Emeritus Professor at Bocconi University and former member (2001-9) and Chairman (2006-7) of the Appellate Body (AB) of the World Trade Organization (WTO).

1 Yuka Fukunaga, 'The Appellate Body's Power to Interpret the WTO Agreements and WTO Members' Power to Disagree with the Appellate Body' (2019) 20 JWIT 792-819; Joshua Paine, 'The WTO's Dispute Settlement Body as a Voice Mechanism' (2019) 20 JWIT 820-861; Geraldo Vidigal, 'Living Without the Appellate Body: Multilateral, Bilateral and Plurilateral Solutions to the WTO Dispute Settlement Crisis' (2019) 20 JWIT 862-89o.

2 See in general Art 26 Vienna Convention of the Law of Treaties (VCLT) ('Pacta sunt servanda'): 'Every treaty is binding upon the parties to it and must be performed in good faith' (indirectly also prohibiting the abuse of rights, such as depriving the other WTO Members of their right to resolve their disputes under the DSU), and, specifically, Art 3.10 Dispute Settlement Understanding (DSU): 'if a dispute arises, all Members will engage in these 
with other WTO members to find a solution to the stalemate. This is despite a number of proposals that several Members have tabled in 2018-2019 in response to US 'concerns', attempting to accommodate them with a view to improving rather than diminishing the functioning of the DSS. This has brought the crisis to its climax, with the cessation of the AB's operation - except for the finalization (hopefully) of appeals pending on 10 December 2019. The consequence has been not just the impossibility for parties to a dispute to appeal a panel report. As Geraldo Vidigal points out, appealing a panel report to a non-operational $\mathrm{AB}$ ('into limbo') will prevent indefinitely its adoption by the Dispute Settlement Body (DSB) and thus prevent the solution of the dispute through rule-based compliance.

It will soon become apparent to all WTO members, as far as they have not realized this already, that recourse to panels, which entails costs and time, in order to obtain redress for anotherWTO Member's breach will become useless. This situation will de facto allow WTO Members to disregard their multilateral obligations since non-compliance will not be ascertained nor sanctioned. ${ }^{3}$ The operation of the WTO will thus be eroded from the inside, and the risk of its irrelevance will become real, notwithstanding the repeatedly proclaimed adherence of most if not all its Members (minus the United States) to the principles of multilateralism in the governance of trade relations.

It is not the purpose of the three papers to discuss the merits of the US criticism. They rather take stock of the current situation in light of the legal and political context and evaluate critically the possible ways out in order to overcome the paralysis of the $\mathrm{AB}$. My summing-up of their different content as well as approaches and of their inter-relation, which justify presenting them together, is as follows.

All three papers take stock of the current crisis to reflect on certain evident shortcomings of the institutional design of the DSS. A shared view is that the deeply embedded consensual modus operandi of the WTO (which serves valuable purposes) hinders even limited changes to the balance between the negotiating (legislative) function of the WTO and adjudication. ${ }^{4}$ At the same

procedures in good faith'. See also Art 17(2) DSU, according to which by positive consensus in accordance with Art 2(4) DSU 'the DSB shall appoint persons to serve on the Appellate Body ... Vacancies shall be filled as they arise' (emphases added).

3 See H Lauterpacht, 'The Function of the Law in the International Community' (OUP 1933, rev ed 2011) 432, as cited by Campbell McLachlan, 'The Assault on International Adjudication and the Limits of Withdrawal' (2019) 68 ICLQ 500, 536: 'the decisive test [for the existence of law] is whether there is a judge competent to decide upon disputed rights and to command peace'.

4 See especially Paine (n 1$) 832$ et seq. 
time, the requirement of consensus cannot or should not be circumvented to resolve the current stalemate, even where it mightbelegally admissible, as underlined especially by Geraldo Vidigal, lest the WTO situation become even more contentious than it currently is. Secondly, the balance established within the DSS between the judicial independence of the adjudicators and their systemic accountability to the membership (the DSB) has been at times problematic also due to the consensus rule. Reframing or rebalancing this relationship (which is at the core of some proposals of reform submitted by various WTO Members to the General Council) presents risks for the impartiality and independence of the $\mathrm{AB}$, and has therefore not commanded widespread support either in the past or at present. Precisely as a consequence of these difficulties in updating the institutional framework so as to take into account the shortcomings and criticisms expressed in this respect by WTO Members - not just the current ones from the United States, but also in the past (for instance as to the $\mathrm{AB}$ having allowed amici curiae briefs) - proposals of amendments to the Dispute Settlement Understanding (DSU) have not been successful, even before the current crisis.

It is not possible for me, nor would it be appropriate, to sum up the content of the papers or enter into a discussion as to their proposals, but some general comments are appropriate. First of all, I would distinguish Joshua Paine's contribution from those by Yuka Fukunaga and Geraldo Vidigal. The first author offers a rare analysis of the role of the DSB, which has the peculiar function of enabling the members of the organization to oversee the operation of the DS function and bodies and to react, collectively but also individually, to the latter's operation.

Paine relies on the well-established framework of 'exit, voice and loyalty', proposed by Albert O. Hirschman in 1970 at the intersection of politics and economics, to explain inter alia a member's response to poor performance in non-economic organizations. ${ }^{5}$ Paine considers that since outright exit from the WTO is not an option, 'voice' is fundamental in order to express dissatisfaction and try to obtain change. Following Joost Pauwelyn and others, he also sees the DSB as a key link with which to convey to adjudicators the sentiment of the WTO members, who are the political 'masters of the treaties', so that the adjudicators' decisions are broadly politically acceptable to the membership.

When it comes to an individual Member's strong dissatisfaction, as is the case currently of the United States, Paine considers that its 'aggressive exercise of voice' has 'been effective in establishing certain pre-conditions for the

5 Albert O Hirschman, Exit, Voice and Loyalty: Responses to Decline in Firms, Organizations, and States (Harvard University Press 1970). 
continued existence of the $\mathrm{AB}$ ' in that many proposals of reform by other Members (and by some academics) 'would alter the relationship between political and adjudicative processes within the WTO' in the direction of scaling-back the relative influence of the $\mathrm{AB}$ and panels. Whatever solution or package of options could be put in place (some of which would not even require formal amendments to the DSU), from increasing dialogue through periodic joint meetings of the DSB and AB to the extreme of removing certain types of politically sensitive disputes from appellate adjudication, the basic stumbling block is the current refusal of the United States to engage in the merits and to reinstate an operational AB. ${ }^{6}$

In this respect, I believe that the framework 'loyalty, voice, exit' could be updated based on the current saga at the WTO. By paralyzing the AB (or 'asphyxiating' it, to use Paine's term), the United States has found a way to paralyze the whole WTO: the United States does not exit the WTO but prevents it from adjudicating the conduct of the United States. The United States will thus be able to resort to measures of dubious or manifest inconsistency with the rules, such as bilateral deals, unilateral imposition of additional tariffs beyond its bound rates, trade restrictions and sanctions. The United States is thus creating for itself a kind of 'WTO à la carte' while other Members try to find ways to re-establish a DSS capable of functioning without the United States, if unavoidable.

Fukunaga's and Vidigal's articles explore some of these alternative options. Fukunaga suggests that WTO Members could better express their individual voices by resorting to individual or joint 'interpretative declarations' to articulate their disagreement with $\mathrm{AB}$ interpretations. In her view, the $\mathrm{AB}$ undoubtedly has the power to make interpretations for the purpose of deciding cases submitted to it since "the power to decide how to reach findings is inherent in every judicial and quasi-judicial organ. ${ }^{7}$ Based on her review of relevant reports, she rightly considers that the $\mathrm{AB}$ 'has generally limited itself

6 See Paine (n 1 ) 856, fn 184 with reference to the US statement at the DSB meeting of 22 July 2019. At that and other DSB meetings in 2018 and 2019, the United States repeated that WTO Members must first 'engage in a deep discussion of why the Appellate Body has felt free to depart from what Members agreed to' (emphasis added). Besides being derogatory towards the 25 plus AB members who have served from the establishment of the WTO up to now (who would have breached the rules instead of applying them!), other Members have not engaged with this 'preliminary objection' because they evidently do not share the criticism and the premise of the United States. They have instead made proposals in the merits in order to increase rather than diminish the efficiency of the AB in the service of the WTO and its Members.

7 Fukunaga (n 1) 797 . 
to narrower interpretative issues that are directly related to the case at hand' and that 'the restrained approach of the $\mathrm{AB}$ is consistent with the principal aim of dispute settlement to "secure a positive solution to a dispute".8 Having examined the relevant reports and in the light of the AB's practice to regularly cite and follow its pronouncements on the interpretation of past cases, she concludes that they 'have precedential effects in the sense that WTO Members have legitimate expectations that they will be followed by panels and the Appellate Body in future cases absent cogent reasons. ${ }^{9}$

As to her proposal, Fukunaga submits first that, " $n$ n] evertheless, the Member cannot be deprived of the power to disagree with the Appellate Body's interpretation and hold its own interpretation' since the DSS does not include the principle of stare decisis, and any interpretation by the $\mathrm{AB}$ is not 'authoritative' (that is binding erga omnes) differently from those issued by the General Council under Article IX(2) of the WTO Agreement. ${ }^{10}$

Fukunaga points out that such declarations are recognized under general international law and are widely used by States. She recognizes that they have a lesser 'probative value' than 'subsequent agreements' and 'subsequent practice' regarding or in the application of a treaty that under Article 31(3)(a) and (b) of the Vienna Convention on the Law Treaties 'shall' be taken into account in its interpretation." However, "this does not mean that the "subjective" interpretation of an individual or several parties to a treaty cannot be taken into account in the interpretation of the treaty, notably as a "supplementary means". ${ }^{12}$ She is therefore of the opinion that it would be useful to give some formal status to such declarations within the DSS, as she proposes articulating various options. In her view, such 'interpretative declarations are not meant to directly correct or override interpretations made by the Appellate Body, but allow Members to at least pronounce their disagreement with the Appellate Body in a more meaningful way than simply "express[ing] their views" at DSB meetings. ${ }^{\prime 13}$

8 ibid.

9 ibid 8o1. The concept of 'cogent reasons' (expressed in WTO, US - Stainless Steel from Mexico, Report of the Appellate Body (30 April 2008) WT/DS $344 / \mathrm{AB} / \mathrm{R}, 160$ et seq) is a 'bête noire' for the United States in its challenge against any precedential effect of past $\mathrm{AB}$ reports. See the 14-page-long summary of the US statement on the 'doctrine of precedent' that the AB would have established 'praeter legem' at the WTO Dispute Settlement Body Meeting of 18 December 2018 (minutes published 4 April 2019) WT/DSB/M/423.

10 Fukunaga (n 1$) 803$.

11 ibid.

12 ibid 811.

13 See Articles 16(2) and (3), 17(14) DSU. 
It is beyond doubt that such unilateral declarations may be relevant in respect of the interpretation of treaties. I wonder however what the value is of such interpretations when they express dissent from an interpretation laid down by the $\mathrm{AB}$ in a report in respect to a given provision of a WTO agreement, besides signaling its position more clearly than just by way of a view expressed in a DSB meeting (in principle when an unfavorable report is adopted). The Member in question may well go on applying a provision according to its own diverging interpretation (an example could be the United States continue using 'zeroing' in antidumping investigations), but it will risk losing a case brought by another Member which relies on the contrary $\mathrm{AB}$ interpretation (except if the $\mathrm{AB}$ would be convinced to change its position on the point).

I come finally to Vidigal's accurate analysis of the options available to the WTO membership to maintain a functioning appellate review of panel reports despite the lack of an operational AB. Vidigal lists three avenues for WTO Members wishing to do so, each bypassing the US blockade as an interim solution (which however risk becoming permanent if the United States would find it convenient ${ }^{14}$ ). The first is to preserve the existence and role of the $\mathrm{AB}$ by appointing its members by majority, which the author rejects as a fragile twisting of the current rules (I agree for the reasons he explains). The second is to conclude a bilateral ad hoc agreement by the parties to a specific dispute by either not appealing or by resorting to an 'appellate arbitration' under Article 25 of the DSU. Both solutions have been put into practice lately. Although Vidigal appreciates the bilateral Canada-EU Appeal Arbitration Arrangement concluded as an interim solution in July 2019 by the EU and Canada to be put in place in case of appeal in disputes between them - he advocates going beyond the bilateral dimension. His preference is for a third avenue, a 'plurilateral solution', which consists of an ex ante agreement to arbitrate, thereby establishing compulsory adjudication among as many WTO Members as possible, perhaps even replacing the panel level.

I have reservations about replacing the panel level with arbitration, an unnecessary change since panels continue functioning. As to the rest of the proposal, I can understand that a formal 'plurilateral' agreement would be preferable to an ad hoc bilateral arrangement because the latter might fail should a party not accept to submit itself to the appeal arbitration when the moment

14 The United States has however criticized the EU-Canada arrangement providing for a bilateral 'appeal arbitration' under Art 25 DSU at the WTO Dispute Settlement Body Meeting of 30 September 2019, WTO/AIR/DSB/85. The United States has submitted that this plan would 'legitimize' bad AB practices since the explicit goal of this contingency plan is to replicate as closely as possible all substantive and procedural aspects as well as practices of the $\mathrm{AB}$ (to many of which the United States objects). 
comes. Doubts as to the feasibility and desirability of such a scheme are rather of a practical nature: how many countries would subscribe to it? Would not a very elaborate scheme risk, if successful, to represent a permanent second best to the multilateral WTO DSS? Would it not legitimize the special position of the United States as a Member of the WTO but not of its DSS?

In any case, the three articles presented here are very valuable contributions, not just in view of their academic rigor but also for the 'food for thought' they offer as to the proper role of international adjudication in general, and specifically to diplomats and policy makers engaged in finding ways to relaunch the WTO and its DSS. ${ }^{15}$

15 For subsequent academic contributions on the issue see Joost Pauwelyn, 'WTO Dispute Settlement Post 2019: What to Expect?' (2019) 22 JIEL 3; Chang-fa Lo, Junji Nakagawa and Tsai-Fang Chen (eds), The Appellate Body of the WTO and Its Reform (Springer 2020) (forthcoming). 